Article

\title{
Bioactive Constituents Obtained from the Seeds of Lepidium apetalum Willd
}

\author{
Sijian Wang ${ }^{1}$, Pingping $\mathrm{Shi}^{2}$, Lu Qu ${ }^{1}$, Jingya Ruan ${ }^{1}$, Shengcai Yang ${ }^{2}$, Haiyang $\mathrm{Yu}^{1}$, \\ Yi Zhang ${ }^{2, *}$ and Tao Wang ${ }^{1, *}$ \\ 1 Tianjin State Key Laboratory of Modern Chinese Medicine, 312 Anshanxi Road, Nankai District, \\ Tianjin 300193, China; 15122587883@163.com (S.W.); qululuhan88@163.com (L.Q.); \\ Ruanjy19930919@163.com (J.R.); yuhaiyang19830116@hotmail.com (H.Y.) \\ 2 Tianjin Key Laboratory of TCM Chemistry and Analysis, Institute of Traditional Chinese Medicine, \\ Tianjin University of Traditional Chinese Medicine, 312 Anshanxi Road, Nankai District, \\ Tianjin 300193, China; shipingpingtcm@163.com (P.S.); 15122473723@163.com (S.Y.) \\ * Correspondence: zhwwxzh@263.net (Y.Z.); wangtao@tjutcm.edu.cn (T.W.); \\ Tel./Fax: +86-22-5959-6163 (Y.Z.); +86-22-5959-6168 (T.W.)
}

Academic Editor: Derek J. McPhee

Received: 25 January 2017; Accepted: 25 March 2017; Published: 28 March 2017

\begin{abstract}
Three new compounds, apetalumosides $C_{1}(1), D(2)$, and 1-thio- $\beta$-D-glucopyranosyl $(1 \rightarrow 1)$ -1-thio- $\alpha$-D-glucopyranoside (3), together with twenty-two known ones (4-25) were obtained from the seeds of Lepidium apetalum Willd. Among the known isolates, 5-8, 10-13, 16-20, and 25 were obtained from the genus for the first time; 4, 14, 15, and 21-24 were isolated from the species for the first time. Meanwhile, the NMR data of $\mathbf{1 6}$ was first reported here. Their structures were determined by means of chemical and spectroscopic methods. On the other hand, their inhibitory effects on sodium oleate-induced triglyceride (TG) overloading in HepG2 cells were evaluated. As a result, two new compounds (1 and 2), together with known isolates 7-11, 13, 14, 16-18, 20, 21, and 25 possessed significant inhibitory effects in the cells.
\end{abstract}

Keywords: Lepidium apetalum; flavonoid glycosides; phenolic glycosides; HepG2 cells; triglyceride accumulation inhibitory effects

\section{Introduction}

In our on-going program of screening the phytochemical and bioactive constituents from Lepidium apetalum seed extract [1,2], three new compounds, apetalumosides $C_{1}(\mathbf{1}), D$ (2), and 1-thio- $\beta$-D-glucopyranosyl $(1 \rightarrow 1)$-1-thio- $\alpha$-D-glucopyranoside (3), along with twenty-two known isolates, astragalin (4) [3]; kaempferol 3-O- $\beta$-D-glucopyranosyl-7-O- $\beta$-D-gentiobioside (5) [4]; drabanemoroside (6) [5]; quercetin 3-O- $\beta$-D-glucopyranosyl-7-O- $\beta$-D-gentiobioside (7) [4]; quercetin 3-O- $\alpha$-L-rhamnopyranosyl $(1 \rightarrow 2)-\alpha$-L-arabinopyranoside (8) [6]; isorhamnetin 3-O- $\beta$-D-glucopyranoside (9) [7]; isorhamnetin 3,4'-O- $\beta$-D-diglucoside (10) [8]; isorhamnetin 3-O- $\beta$-D-glucopyranosyl-7-O- $\beta$-D-gentiobioside (11) [4]; 2-O-(3,4-dihydroxybenzoyl)-2,4,6- trihydroxy phenylacetic acid 4-O- $\beta$-D-glucopyranoside (12) [9]; 4,9-di-O- $\beta$-D-glucosyl sinapoyl alcohol (13) [10]; $3^{\prime}, 5^{\prime}$-dimethoxy-4-O- $\beta$-D-glucopyranosyl cinnamic acid (14) [11]; sinapoylglucose (15) [12]; sinapoyl-9-sucrosecoside (16); 1(E),2(E)-di-O-sinapoyl- $\beta$-D-glucopyranoside (17) [13]; 1,2-disinapoylgentiobiose (18) [14]; lariciresinol 4'-O- $\beta$-D-glucopyranoside (19) $[15,16]$; $(7 S, 8 R)$ aegineoside (20) [17,18]; L-tryptophan (21) [19]; thymidine (22) [20]; adenosine (23) [21]; stachyose (24) [22]; and TgSSTg (25) [23] were obtained. Among the known isolates, 5-8, 10-13, 16-20, and 25 were obtained from the genus for the first time. Meanwhile, 4, 14, 15, and 21-24 were isolated from the species for the first time, and the NMR data of $\mathbf{1 6}$ was first reported here. Moreover, as the 
active ingredients of the hypolipidemic effect, several phenolic compounds, including five flavonoids (7-11), five sinapic acid homologues $(\mathbf{1 3}, \mathbf{1 4}$, and 16-18), and one lignan (20), together with two new compounds ( $\mathbf{1}$ and $\mathbf{2}$ ), as well as two other isolates (21 and 25) exhibited significant triglyceride (TG)-lowering effects in HepG2 cells.

\section{Results and Discussion}

The $50 \%$ EtOH extract of L. apetalum seeds was treated with the same experimental process as reported in reference [1,2] to obtain $95 \%$ EtOH eluate, which was separated by silica gel, octadecylsilica (ODS), Sephadex LH-20 CC, and finally preparative HPLC to yield compounds 1-25. Their structures are shown in Figures 1 and 2.
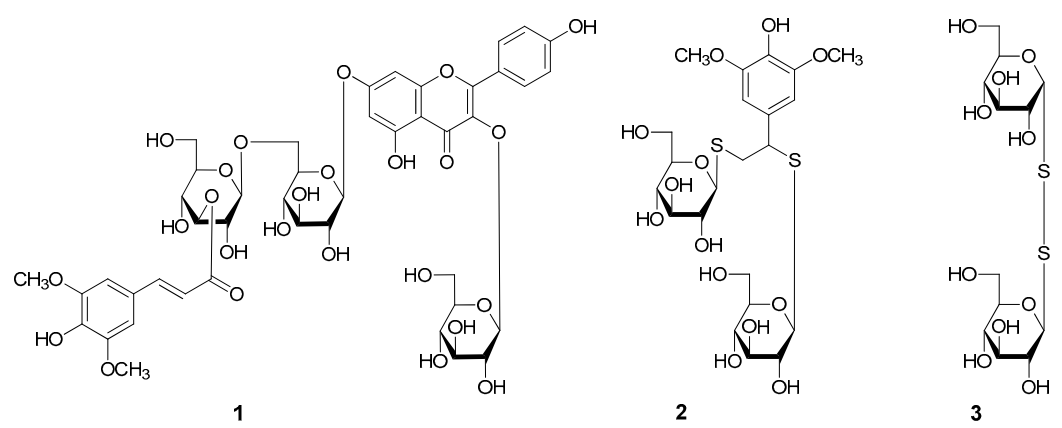

Figure 1. The new compounds 1-3 obtained from the seeds of L. apetalum.
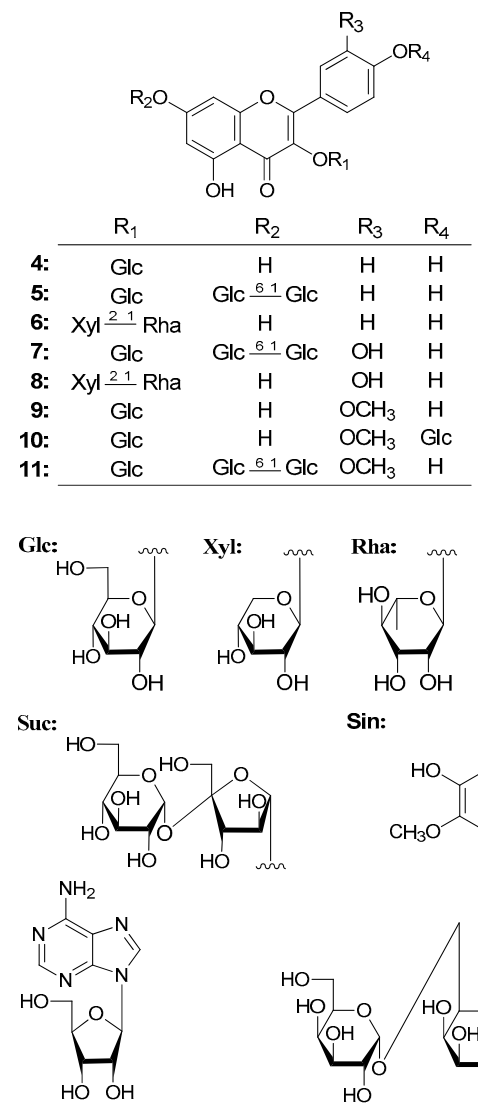

23

Sin:<smiles>O=C(Oc1cc(O)cc(O)c1C(=O)O)c1ccc(O)c(O)c1</smiles><smiles>[2H]C(=O)C=Cc1cc(O)c(O)c(OC)c1</smiles>

12<smiles>COc1cc(/C=C/COC(C)=O)cc(OC)c1OC(O)(Cl)Cl</smiles>

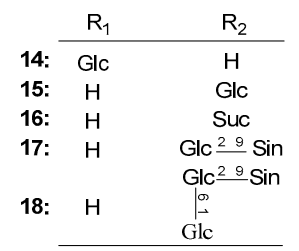<smiles>COc1ccc(C[C@@H]2COC(c3ccc(OC)c(OC)c3)[C@H]2CO)cc1OC</smiles>

19

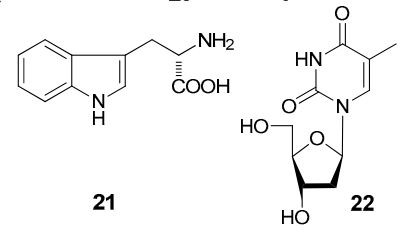<smiles>[3H]OC(=O)/C=C/c1cc(OC)c(O)c(OC)c1</smiles>
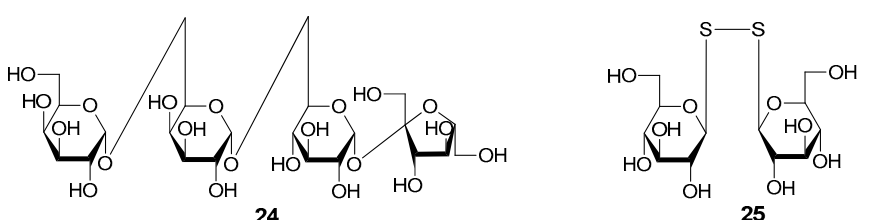

Figure 2. The known compounds (4-25) obtained from the seeds of L. apetalum. 
Apetalumoside $C_{1}(\mathbf{1})$ was isolated as yellow powder with negative optical rotation $\left([\alpha]_{\mathrm{D}}^{25}-41.1^{\circ}\right.$, $\mathrm{MeOH})$. Its molecular formula was deduced as $\mathrm{C}_{44} \mathrm{H}_{50} \mathrm{O}_{25}$ from a $[\mathrm{M}-\mathrm{H}]^{-}$quasi-molecular ion at $m / z$ 977.2555 (calcd. for $\mathrm{C}_{44} \mathrm{H}_{49} \mathrm{O}_{25}, 977.2568$ ) in the negative-ion HRESI-TOF-MS spectrum. The ${ }^{1} \mathrm{H}-,{ }^{13} \mathrm{C}-\mathrm{NMR}$ (Table 1) and 2D NMR $\left({ }^{1} \mathrm{H}^{-1} \mathrm{H}\right.$ COSY, HSQC, HMBC, HSQC-TOCSY) spectra revealed the occurrence of one kaempferol aglycon $(\delta 6.51(1 \mathrm{H}$, br. s, H-6), $6.85(1 \mathrm{H}, \mathrm{br} . \mathrm{s}, \mathrm{H}-8), 6.92(2 \mathrm{H}, \mathrm{d}$, $\left.J=9.0 \mathrm{~Hz}, \mathrm{H}-3^{\prime}, 5^{\prime}\right), 8.09\left(2 \mathrm{H}, \mathrm{d}, J=9.0 \mathrm{~Hz}, \mathrm{H}-2^{\prime}, 6^{\prime}\right), 12.65(1 \mathrm{H}$, br. s, 5-OH)); three $\beta$-D-glucopyranosyl $\left(\delta 4.35\left(1 \mathrm{H}, \mathrm{d}, J=8.0 \mathrm{~Hz}, \mathrm{H}-1^{\prime \prime \prime \prime}\right), 5.12\left(1 \mathrm{H}, \mathrm{d}, J=7.0 \mathrm{~Hz}, \mathrm{H}-1^{\prime \prime \prime}\right), 5.50\left(1 \mathrm{H}, \mathrm{d}, J=8.0 \mathrm{~Hz}, \mathrm{H}-1^{\prime \prime}\right)\right)$; along with one sinapoyl $\left(\delta_{\mathrm{H}} 3.81\left(6 \mathrm{H}, \mathrm{s}, 3^{\prime \prime \prime \prime \prime \prime}, 5^{\prime \prime \prime \prime \prime \prime}-\mathrm{OCH}_{3}\right), 6.53\left(1 \mathrm{H}, \mathrm{d}, J=16.0 \mathrm{~Hz}, \mathrm{H}-8^{\prime \prime \prime \prime \prime}\right), 7.00\right.$ $\left.\left(2 \mathrm{H}, \mathrm{s}, \mathrm{H}-2^{\prime \prime \prime \prime \prime}, 6^{\prime \prime \prime \prime \prime}\right), 7.51\left(1 \mathrm{H}, \mathrm{d}, J=16.0 \mathrm{~Hz}, \mathrm{H}-7^{\prime \prime \prime \prime \prime}\right) ; \delta_{\mathrm{C}} 166.2\left(\mathrm{C}-9^{\prime \prime \prime \prime \prime \prime}\right)\right)$. Meanwhile, in the HMBC experiment, the long-range correlations from $\mathrm{H}-1^{\prime \prime}$ to $\mathrm{C}-3 ; \mathrm{H}-1^{\prime \prime \prime}$ to $\mathrm{C}-7 ; \mathrm{H}-1^{\prime \prime \prime \prime}$ to $\mathrm{C}-6^{\prime \prime \prime}$; $\mathrm{H}-3^{\prime \prime \prime \prime}$ to C- $9^{\prime \prime \prime \prime \prime \prime}$ were observed, then the connectivities between oligoglycoside moieties and aglycon or sinapoyl groups were characterized. Finally, a HSQC-TOCSY experiment was developed to assign the badly overlapped protons in the sugar chemical shift range. In the HSQC-TOCSY spectrum, correlations between the following proton and carbon pairs were observed: $\delta_{\mathrm{C}} 100.6\left(\mathrm{C}-1^{\prime \prime}\right)$ and $\delta_{\mathrm{H}} 3.08\left(\mathrm{H}-4^{\prime \prime}\right)$, $3.21\left(\mathrm{H}-2^{\prime \prime}\right), 3.26\left(\mathrm{H}-3^{\prime \prime}\right), 5.50\left(\mathrm{H}-1^{\prime \prime}\right) ; \delta_{\mathrm{H}} 3.08\left(\mathrm{H}-4^{\prime \prime}\right)$ and $\delta_{\mathrm{C}} 60.8\left(\mathrm{C}-6^{\prime \prime}\right), 69.8\left(\mathrm{C}-4^{\prime \prime}\right), 74.2\left(\mathrm{C}-2^{\prime \prime}\right), 76.3$ $\left(\mathrm{C}-5^{\prime \prime}\right), 76.8\left(\mathrm{C}-3^{\prime \prime}\right) ; \delta_{\mathrm{H}} 5.12\left(\mathrm{H}-1^{\prime \prime \prime}\right)$ and $\delta_{\mathrm{C}} 69.2\left(\mathrm{C}-4^{\prime \prime \prime}\right), 73.0\left(\mathrm{C}-2^{\prime \prime \prime}\right), 76.2\left(\mathrm{C}-3^{\prime \prime \prime}\right), 99.7\left(\mathrm{C}-1^{\prime \prime \prime}\right) ; \delta_{\mathrm{H}} 3.71$, $3.99\left(\mathrm{H}_{2}-6^{\prime \prime \prime}\right)$ and $\delta_{\mathrm{C}} 68.9\left(\mathrm{C}-6^{\prime \prime \prime}\right), 69.2\left(\mathrm{C}-4^{\prime \prime \prime}\right), 73.0\left(\mathrm{C}-2^{\prime \prime \prime}\right), 75.3\left(\mathrm{C}-5^{\prime \prime \prime}\right), 76.2\left(\mathrm{C}-3^{\prime \prime \prime}\right) ; \delta_{\mathrm{C}} 103.5\left(\mathrm{C}-1^{\prime \prime \prime \prime \prime}\right)$ and $\delta_{\mathrm{H}} 3.22\left(\mathrm{H}-2^{\prime \prime \prime \prime}\right), 3.34\left(\mathrm{H}-4^{\prime \prime \prime \prime}\right), 4.35\left(\mathrm{H}-1^{\prime \prime \prime \prime}\right), 4.90\left(\mathrm{H}-3^{\prime \prime \prime \prime}\right) ; \delta_{\mathrm{H}} 4.90\left(\mathrm{H}-3^{\prime \prime \prime \prime}\right)$ and $\delta_{\mathrm{C}} 60.7\left(\mathrm{C}-6^{\prime \prime \prime \prime}\right)$, $68.1\left(\mathrm{C}-4^{\prime \prime \prime \prime}\right), 77.4\left(\mathrm{C}-5^{\prime \prime \prime \prime}\right), 103.5\left(\mathrm{C}-1^{\prime \prime \prime \prime}\right)$. Acid hydrolysis of $\mathbf{1}$ yielded D-glucose, which was identified by retention time and optical rotation using chiral detection by HPLC analysis $[1,2]$.

Table 1. ${ }^{1} \mathrm{H}$ - and ${ }^{13} \mathrm{C}-\mathrm{NMR}$ data for 1 in DMSO- $d_{6}$.

\begin{tabular}{|c|c|c|c|c|c|}
\hline No. & $\delta_{C}$ & $\delta_{H}(J$ in $\mathrm{Hz})$ & No. & $\delta_{C}$ & $\delta_{\mathbf{H}}(J$ in $\mathrm{Hz})$ \\
\hline 2 & 156.7 & - & $2^{\prime \prime \prime}$ & 73.0 & $3.28(\mathrm{dd}, 7.0,9.5)$ \\
\hline 3 & 133.4 & - & $3^{\prime \prime \prime}$ & 76.2 & $3.32(\mathrm{dd}, 9.5,9.5)$ \\
\hline 4 & 177.6 & - & $4^{\prime \prime \prime}$ & 69.2 & $3.26(\mathrm{~m}$, overlapped $)$ \\
\hline 5 & 160.8 & - & $5^{\prime \prime \prime}$ & 75.3 & $3.75(\mathrm{~m})$ \\
\hline 6 & 99.4 & 6.51 (br. s) & $6^{\prime \prime \prime}$ & 68.9 & $3.71(\mathrm{dd}, 5.5,11.5)$ \\
\hline 7 & 162.7 & - & & & 3.99 (br. d, ca. 12) \\
\hline 8 & 94.4 & 6.85 (br. s) & $1^{\prime \prime \prime \prime}$ & 103.5 & $4.35(\mathrm{~d}, 8.0)$ \\
\hline 9 & 155.9 & - & $2^{\prime \prime \prime \prime}$ & 71.5 & $3.22(\mathrm{dd}, 7.5,8.0)$ \\
\hline 10 & 105.6 & - & $3^{\prime \prime \prime \prime}$ & 77.5 & $4.90(\mathrm{dd}, 7.5,9.0)$ \\
\hline $1^{\prime}$ & 120.7 & - & $4^{\prime \prime \prime \prime}$ & 68.1 & $3.34(\mathrm{dd}, 9.0,9.0)$ \\
\hline $2^{\prime}, 6^{\prime}$ & 130.9 & $8.09(\mathrm{~d}, 9.0)$ & $5^{\prime \prime \prime \prime}$ & 77.4 & $3.08(\mathrm{~m})$ \\
\hline $3^{\prime}, 5^{\prime}$ & 115.2 & $6.92(\mathrm{~d}, 9.0)$ & $6^{\prime \prime \prime \prime}$ & 60.7 & 3.56 (br. d, ca. 12) \\
\hline $4^{\prime}$ & 160.1 & - & & & $3.70(\mathrm{dd}, 5.5,11.5)$ \\
\hline $5-\mathrm{OH}$ & - & 12.65 (br. s) & $1^{\prime \prime \prime \prime \prime \prime}$ & 124.5 & - \\
\hline $1^{\prime \prime}$ & 100.6 & $5.50(\mathrm{~d}, 8.0)$ & $2^{\prime \prime \prime \prime \prime \prime}, 6^{\prime \prime \prime \prime \prime \prime}$ & 105.9 & $7.00(\mathrm{~s})$ \\
\hline $2^{\prime \prime}$ & 74.2 & $3.21(\mathrm{dd}, 7.5,8.0)$ & $3^{\prime \prime \prime \prime \prime \prime}, 5^{\prime \prime \prime \prime \prime \prime}$ & 147.9 & - \\
\hline $3^{\prime \prime}$ & 76.8 & $3.26(\mathrm{~m}$, overlapped $)$ & $4^{\prime \prime \prime \prime \prime \prime}$ & 138.0 & - \\
\hline $4^{\prime \prime}$ & 69.8 & $3.08(\mathrm{~m}$, overlapped $)$ & $7^{\prime \prime \prime \prime \prime \prime}$ & 144.9 & $7.51(\mathrm{~d}, 16.0)$ \\
\hline $5^{\prime \prime}$ & 76.3 & $3.21(\mathrm{~m})$ & $8^{\prime \prime \prime \prime \prime \prime}$ & 115.5 & $6.53(\mathrm{~d}, 16.0)$ \\
\hline \multirow[t]{2}{*}{$6^{\prime \prime}$} & 60.8 & 3.30 (br. d, ca. 11) & $9^{\prime \prime \prime \prime \prime \prime}$ & 166.2 & - \\
\hline & & $3.50(\mathrm{dd}, 5.5,10.5)$ & $3^{\prime \prime \prime \prime \prime}, 5^{\prime \prime \prime \prime \prime \prime}-\mathrm{OCH}_{3}$ & 56.0 & $3.81(\mathrm{~s})$ \\
\hline $1^{\prime \prime \prime}$ & 99.7 & $5.12(\mathrm{~d}, 7.0)$ & & & \\
\hline
\end{tabular}

Apetalumoside D (2), white powder, exhibited negative optical rotation $\left([\alpha]_{D}^{25}-35.3^{\circ}\right.$, in $\left.\mathrm{MeOH}\right)$. In the positive-ion HRESI-TOF-MS of 2, the quasi-molecular ion peak was observed at $m / z 593.1333$ $[\mathrm{M}+\mathrm{Na}]^{+}$(calcd. for $\mathrm{C}_{22} \mathrm{H}_{34} \mathrm{O}_{13} \mathrm{~S}_{2} \mathrm{Na}$, 593.1333), and its molecular formula was revealed to be $\mathrm{C}_{22} \mathrm{H}_{34} \mathrm{O}_{13} \mathrm{~S}_{2}$. The ${ }^{1} \mathrm{H}-,{ }^{13} \mathrm{C}-\mathrm{NMR}$ spectra (Table 2) indicated the presences of one symmetrical 1,3,4,5-tetrasubstituted benzene ring $(\delta 6.58(2 \mathrm{H}, \mathrm{s}, \mathrm{H}-2,6))$; two methoxyl $\left(\delta 3.75\left(6 \mathrm{H}, \mathrm{s}, 3,5-\mathrm{OCH}_{3}\right)\right)$; one oxygenated methene $\left(\delta 3.18(1 \mathrm{H}\right.$, br. d, ca. $\left.J=11 \mathrm{~Hz}), 3.39(1 \mathrm{H}, \mathrm{dd}, J=5.0,11.0 \mathrm{~Hz}), \mathrm{H}_{2}-8\right)$; one methine bearing an oxygen function $(\delta 4.28(1 \mathrm{H}, \mathrm{br} . \mathrm{d}$, ca. $J=5 \mathrm{~Hz}, \mathrm{H}-7))$; along with two 
1-thio- $\beta$-D-glucopyranosyl $\left(\delta 4.27\left(1 \mathrm{H}, \mathrm{d}, J=10.0 \mathrm{~Hz}, \mathrm{H}-1^{\prime \prime}\right), 4.31\left(1 \mathrm{H}, \mathrm{d}, J=9.5 \mathrm{~Hz}, \mathrm{H}-1^{\prime}\right)\right)$ [24]. The ${ }^{1} \mathrm{H}-{ }^{1} \mathrm{H}$ COSY experiment on 2 indicated the presence of three partial structures shown in bold bonds (Figure 3). Finally, the planar structure of apetalumoside $\mathrm{D}(2)$ was determined by the long-range correlations from $\mathrm{H}-2,6$ to $\mathrm{C}-1,3-5,7 ; 3,5-\mathrm{OCH}_{3}$ to $\mathrm{C}-3,5 ; \mathrm{H}-7$ to $\mathrm{C}-1,2,6,8, \mathrm{C}-1^{\prime} ; \mathrm{H}-1^{\prime}$ to $\mathrm{C}-7 ; \mathrm{H}-1^{\prime \prime}$ to $\mathrm{C}-8$ observed in its $\mathrm{HMBC}$ spectrum. The ${ }^{1} \mathrm{H}-$ and ${ }^{13} \mathrm{C}-\mathrm{NMR}$ data of 2 was assigned by the correlations from proton to carbon displayed in the HSQC spectrum.
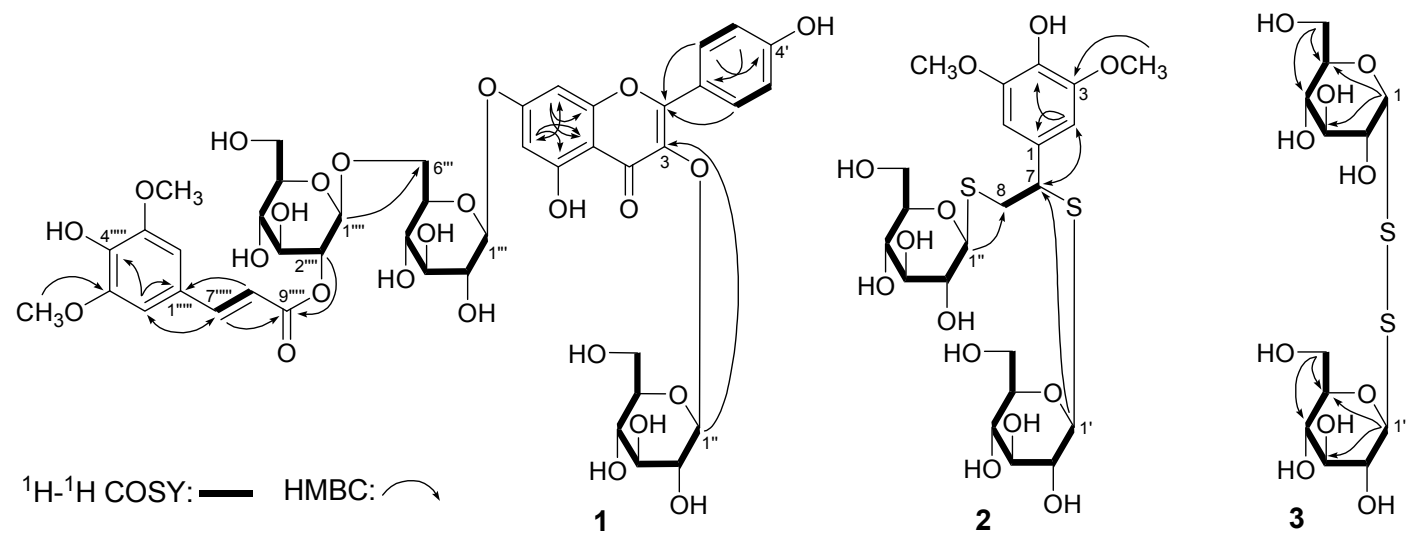

Figure 3. The main ${ }^{1} \mathrm{H}^{-1} \mathrm{H}$ COSY and $\mathrm{HMBC}$ correlations of $\mathbf{1}-\mathbf{3}$.

Table 2. ${ }^{1} \mathrm{H}$ - and ${ }^{13} \mathrm{C}-\mathrm{NMR}$ data for 2 in DMSO- $d_{6}$.

\begin{tabular}{|c|c|c|c|c|c|}
\hline No. & $\delta_{\mathrm{C}}$ & $\delta_{\mathrm{H}}(J$ in $\mathrm{Hz})$ & No. & $\delta_{\mathrm{C}}$ & $\delta_{\mathrm{H}}(J$ in $\mathrm{Hz})$ \\
\hline 1 & 130.2 & - & $4^{\prime}$ & $70.0^{\mathrm{a}}$ & $3.07(\mathrm{~m}$, overlapped $)$ \\
\hline 2,6 & 105.6 & $6.58(\mathrm{~s})$ & $5^{\prime}$ & 78.1 & 3.12 (m, overlapped) \\
\hline 3,5 & 147.5 & - & $6^{\prime}$ & $61.2^{b}$ & $3.46(\mathrm{dd}, 5.0,12.5)$ \\
\hline 4 & 134.5 & - & & & 3.70 (br. d, ca. 13) \\
\hline 7 & 46.5 & 4.28 (br. d, ca. 5) & $1^{\prime \prime}$ & 84.7 & $4.27(\mathrm{~d}, 10.0)$ \\
\hline \multirow[t]{2}{*}{8} & 34.8 & 3.18 (br. d, ca. 11) & $2^{\prime \prime}$ & 80.8 & 3.13 (m, overlapped) \\
\hline & & $3.39(\mathrm{dd}, 5.0,11.0)$ & $3^{\prime \prime}$ & 78.0 & 3.12 (m, overlapped) \\
\hline $3,5-\mathrm{OCH}_{3}$ & 55.9 & $3.75(\mathrm{~s})$ & $4^{\prime \prime}$ & $69.9^{\mathrm{a}}$ & 3.07 (m, overlapped) \\
\hline $1^{\prime}$ & 83.7 & $4.31(\mathrm{~d}, 9.5)$ & $5^{\prime \prime}$ & 72.9 & $3.01(\mathrm{dd}, 9.5,10.0)$ \\
\hline $2^{\prime}$ & 72.9 & $3.01(\mathrm{dd}, 8.0,9.5)$ & $6^{\prime \prime}$ & $61.1^{\mathrm{b}}$ & $3.46(\mathrm{dd}, 5.0,12.5)$ \\
\hline $3^{\prime}$ & 80.8 & $3.13(\mathrm{~m}$, overlapped $)$ & & & 3.70 (br. d, ca. 13) \\
\hline
\end{tabular}

The molecular formula of 1-thio- $\beta$-D-glucopyranosyl $(1 \rightarrow 1)-1$-thio- $\alpha$-D-glucopyranoside (3) was deduced as $\mathrm{C}_{12} \mathrm{H}_{22} \mathrm{O}_{10} \mathrm{~S}_{2}$ from a $[\mathrm{M}+\mathrm{H}]^{+}$quasi-molecular ion at $m / z 391.0739$ (calcd. for $\mathrm{C}_{12} \mathrm{H}_{23} \mathrm{O}_{10} \mathrm{~S}_{2}$, 391.0727). Twelve signals were displayed in its ${ }^{13} \mathrm{C}-\mathrm{NMR}$ (Table 3) spectrum, and all of their chemical shifts appeared in the field of 60-100. The correlations from $\delta_{\mathrm{H}} 4.68\left(1 \mathrm{H}, \mathrm{d}, J=9.0 \mathrm{~Hz}, \mathrm{H}-1^{\prime}\right)$ to $\delta_{\mathrm{C}}$ $92.4\left(\mathrm{C}-1^{\prime}\right)$, and $\delta_{\mathrm{H}} 5.57(1 \mathrm{H}, \mathrm{d}, J=5.5 \mathrm{~Hz}, \mathrm{H}-1)$ to $\delta_{\mathrm{C}} 96.1(\mathrm{C}-1)$ observed in the HSQC spectrum indicated that there were two sugar units in 3. Combined with its MS and ${ }^{1} \mathrm{H}-\mathrm{NMR}$ spectrum (Table 3), the presence of two 1-thio-glucopyranosyl parts were conjectured. Among them, the anomeric proton $\left(\delta_{\mathrm{H}} 4.68\left(\mathrm{H}-1^{\prime}\right)\right)$ and a set of ${ }^{13} \mathrm{C}-\mathrm{NMR}\left(\delta_{\mathrm{C}} 63.7\left(\mathrm{C}-6^{\prime}\right), 72.1\left(\mathrm{C}-4^{\prime}\right), 74.4\left(\mathrm{C}-2^{\prime}\right), 80.0\right.$ $\left.\left(\mathrm{C}-3^{\prime}\right), 83.1\left(\mathrm{C}-5^{\prime}\right), 92.4\left(\mathrm{C}-1^{\prime}\right)\right)$ signals revealed the presence of 1-thio- $\beta$-D-glucopyranosyl [23,24]. Meanwhile, the presence of 1-thio- $\alpha$-D-glucopyranosyl was presumed by the following signals: $\delta_{\mathrm{H}}$ $5.57(\mathrm{H}-1)$, and $\delta_{\mathrm{C}} 63.4(\mathrm{C}-6), 72.3(\mathrm{C}-4), 74.3(\mathrm{C}-2), 76.2(\mathrm{C}-3), 76.4(\mathrm{C}-5), 96.1(\mathrm{C}-1)$. Moreover, all of the coupling constants between $\mathrm{H}-2$ and $\mathrm{H}-3, \mathrm{H}-3$ and $\mathrm{H}-4, \mathrm{H}-4$ and $\mathrm{H}-5$ were $9.5 \mathrm{~Hz}$, which indicated that the protons in C-2, 3, 4, 5 were in axial bond. On the other hand, $\mathrm{H}-1$ was suggested to be in equatorial bond by $J_{\mathrm{H}-1,2}=5.5 \mathrm{~Hz}$. Finally, the nuclear overhauser effect (NOE) correlations between $\mathrm{H}-2$ and $\mathrm{H}-1, \mathrm{H}-4 ; \mathrm{H}-3$ and $\mathrm{H}-5$ observed in the NOESY experiment, further proved the presence of 
1-thio- $\alpha$-D-glucopyranosyl. The assignment of protons and carbons was reached by the ${ }^{1} \mathrm{H}-{ }^{1} \mathrm{H}$ COSY, HSQC, and HMBC spectra. On the basis of the above mentioned evidence, the structure of 3 was elucidated to be 1 -thio- $\beta$-D-glucopyranosyl $(1 \rightarrow 1)$-1-thio- $\alpha$-D-glucopyranoside (3).

Table 3. ${ }^{1} \mathrm{H}$ - and ${ }^{13} \mathrm{C}-\mathrm{NMR}$ data for 3 in $\mathrm{D}_{2} \mathrm{O}$.

\begin{tabular}{cccccc}
\hline No. & $\boldsymbol{\delta}_{\mathbf{C}}$ & $\delta_{\mathbf{H}}(\boldsymbol{J}$ in $\mathbf{H z})$ & No. & $\delta_{\mathbf{C}}$ & $\delta_{\mathbf{H}}(\boldsymbol{J}$ in $\mathbf{H z})$ \\
\hline 1 & 96.1 & $5.57(\mathrm{~d}, 5.5)$ & $1^{\prime}$ & 92.4 & $4.68(\mathrm{~d}, 9.0)$ \\
2 & 74.3 & $3.87(\mathrm{dd}, 5.5,9.5)$ & $2^{\prime}$ & 74.4 & $3.49(\mathrm{dd}, 9.0,9.5)$ \\
3 & 76.2 & $3.58(\mathrm{dd}, 9.5,9.5)$ & $3^{\prime}$ & 80.0 & $3.52(\mathrm{dd}, 9.5,9.5)$ \\
4 & 72.3 & $3.44(\mathrm{dd}, 9.5,9.5)$ & $4^{\prime}$ & 72.1 & $3.42(\mathrm{dd}, 9.5,9.5)$ \\
5 & 76.4 & $3.94(\mathrm{~m})$ & $5^{\prime}$ & 83.1 & $3.50(\mathrm{~m})$ \\
6 & 63.4 & $3.80(\mathrm{dd}, 5.5,12.5)$ & $6^{\prime}$ & 63.7 & $3.72(\mathrm{dd}, 5.5,12.5)$ \\
& & $3.88(\mathrm{dd}, 1.5,12.5)$ & & & $3.91(\mathrm{dd}, 1.5,12.5)$ \\
\hline
\end{tabular}

The L. apetalum isolates were evaluated for their inhibitory activities on TG overloading by the model of sodium oleate (SO)-induced fatty liver in vitro. As shown in Figure 4, compounds 1, 2, 7-10, 11, 13, 14, 16-18, 20, 21 and 25 exhibited significant TG-lowering effects, among which, 10, 13 and 21 showed levels of activities almost equivalent to the positive control-a TG clearance rate of about $22 \%$-and the remainders also reached at least $4.02 \% \pm 1.57 \%$.
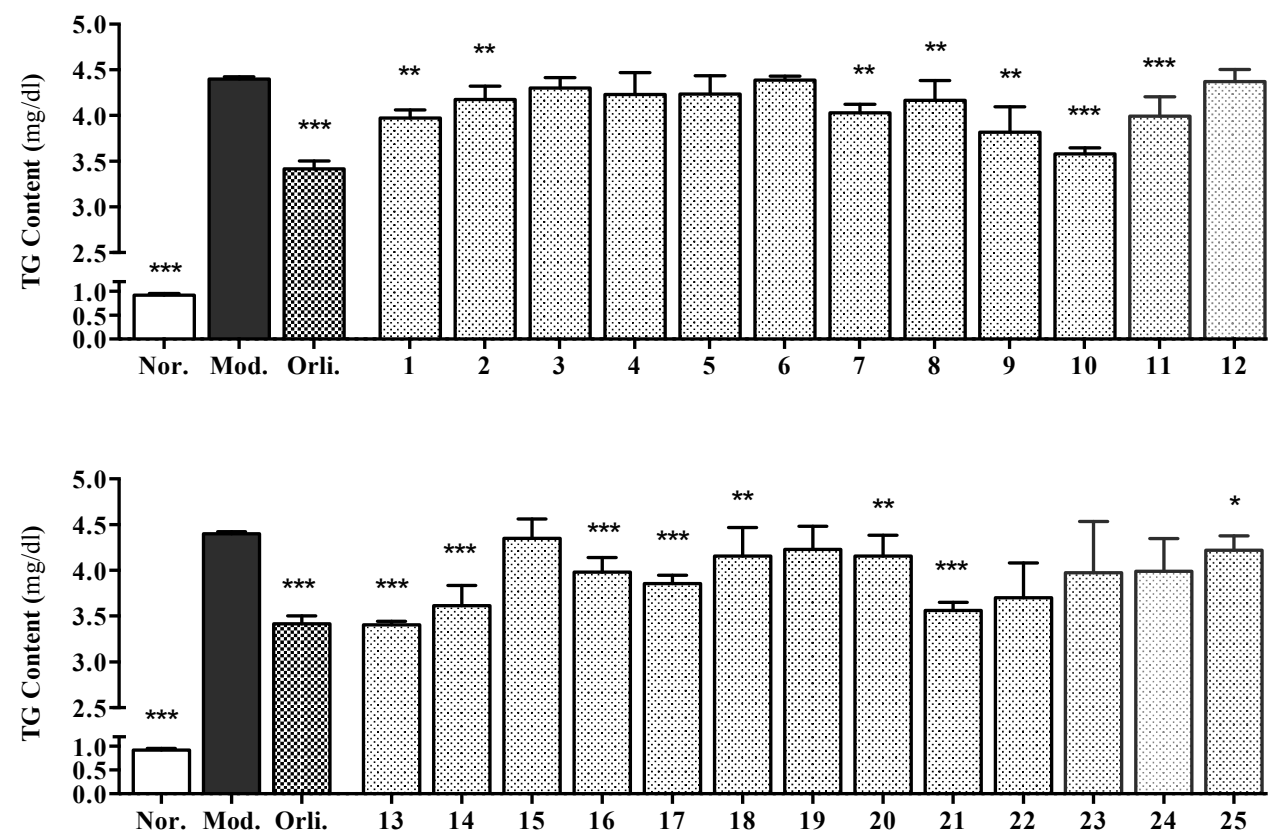

Figure 4. Effects of compounds 1-25 on TG overloading in HepG2 cells. Cells were treated with $200 \mu \mathrm{mol} / \mathrm{L}$ sodium oleate (SO) for $48 \mathrm{~h}$. Meanwhile, $30 \mu \mathrm{mol} / \mathrm{L}$-tested compounds or $5 \mu \mathrm{mol} / \mathrm{L}$-orlistat (Orli.) were co-incubated to evaluate their inhibitory effects, respectively. Each value represents the mean \pm S.E.M., $n=4{ }^{* * *} p<0.001,{ }^{* *} p<0.01,{ }^{*} p<0.05$ vs. model group (Mod.). Nor. = normal group.

According to the results shown in Figure 5, the tested compounds 7, 8, 17, 20 and 25 showed different dose-activity relationships. In response to stimulations of 7, 8 and $\mathbf{1 7}$ (at 30, 3 and $0.3 \mu \mathrm{mol} / \mathrm{L}$ ), or 20 and 25 (at 100, 30, 3 and $0.3 \mu \mathrm{mol} / \mathrm{L}$ ), gradual decrement trends of TG overloading were observed (shown in Tables 4 and 5).

As for structure-activity relationships, quercetin glycosides (7 and 8) and isorhamnetin glycosides (9-11) in the current study showed significant TG-lowering effects, while kaempferol glycosides (4-6) exhibited no obvious activity, which indicated that the $3^{\prime}$-position substitution of hydroxyl or methoxy 
might play critical roles on the TG-lowering activity of flavone glycosides. For apetalumoside C1 (1), a previous study has reported that the substitution of 7-position by $O$-glycosides would reduce the inhibitory activities of flavonoid glycosides [2], while in the current study, 1 still exhibited a strong effect with the glycosylation of 7-hydroxyl; this is speculated to be due to the presence of the sinapoyl group in the structure. Meanwhile, five of the six sinapic acid homologues in our study, including 13, 14, and 16-18, showed significant TG-lowering activities. By comparing the TG clearance rate of $17(12.39 \% \pm 0.95 \%)$ with that of $18(5.49 \% \pm 3.17 \%)$, at the concentration of $30 \mu \mathrm{mol} / \mathrm{L}$, as well as the difference of their structures, we speculated that the one additional glycosyl might be the reason for the reduced activity. However, it is noteworthy that sinapoylglucose (15) showed lower activity than that of sinapoyl-9-sucrosecoside (16), which made it complicated to illustrate the influence of the substituted position and amount of glycosyl on the activity of sinapic acid groups.

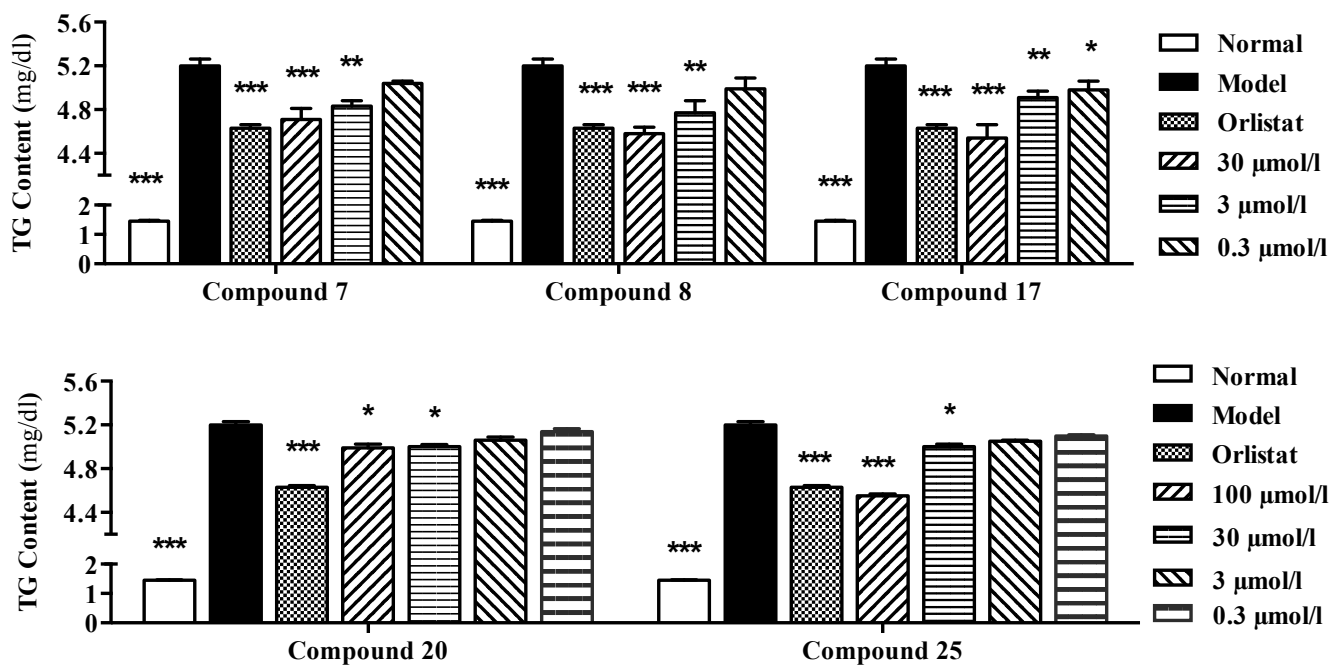

Figure 5. Concentration-dependent inhibitory effects of compounds 7, 8, 17, 20, and 25 on TG overloading in HepG2 cells. Cells were treated with $200 \mu \mathrm{mol} / \mathrm{L}$ SO for $48 \mathrm{~h}$. Meanwhile, different indicated concentrations of tested compounds were co-incubated to perform the dose dependency study, respectively. Each value represents the mean \pm S.E.M., $n=4,{ }^{* * *} p<0.001,{ }^{* *} p<0.01,{ }^{*} p<0.05$ vs. model group (Mod.). Nor. = normal group.

Table 4. TG clearance of compounds 7, 8 and 17 at different concentrations.

\begin{tabular}{ccccccccc}
\hline $\begin{array}{c}\text { Sample } \\
(\boldsymbol{\mu m o l} / \mathrm{L})\end{array}$ & $\mathbf{3 0}$ & $\mathbf{3}$ & $\mathbf{0 . 3}$ & $\mathbf{3 0}$ & $\mathbf{3}$ & $\mathbf{0 . 3}$ & $\mathbf{3 0}$ & $\mathbf{1 7}$ \\
\cline { 2 - 8 } & $7.16 \pm 0.87$ & $3.24 \pm 0.35$ & $12.00 \pm 1.17$ & $8.27 \pm 2.14$ & $4.15 \pm 1.97$ & $12.70 \pm 2.39$ & $5.68 \pm 1.15$ & $4.32 \pm 1.57$ \\
\hline $\begin{array}{c}\text { TG clearance } \\
(\%)\end{array}$ & $9.46 \pm 1.89$ & 7.15 & $\mathbf{0 . 3}$ \\
\hline
\end{tabular}

Table 5. TG clearance of compounds 20 and 25 at different concentrations.

\begin{tabular}{|c|c|c|c|c|c|c|c|c|}
\hline \multirow{2}{*}{$\begin{array}{l}\text { Sample } \\
(\mu \mathrm{mol} / \mathrm{L})\end{array}$} & \multicolumn{4}{|c|}{20} & \multicolumn{4}{|c|}{25} \\
\hline & 100 & 30 & 3 & 0.3 & 100 & 30 & 3 & 0.3 \\
\hline $\begin{array}{c}\text { TG clearance } \\
(\%)\end{array}$ & $4.14 \pm 1.40$ & $3.91 \pm 1.79$ & $2.82 \pm 1.06$ & $1.31 \pm 1.02$ & $12.66 \pm 0.77$ & $3.91 \pm 0.90$ & $2.96 \pm 0.45$ & $2.00 \pm 0.34$ \\
\hline
\end{tabular}

\section{Experimental}

\subsection{General}

Ultraviolet-visible spectroscopy (UV) and Infrared Spectroscopy (IR) spectra were recorded on a Varian Cary 50 UV-Vis (Varian Australia Pty Ltd., Mulgrave, Australia) and Varian 640-IR FT-IR spectrophotometer (Varian, Inc., Hubbardsdon, MA, USA), respectively. Optical rotations 
were measured on a Rudolph Autopol IV automatic polarimeter (Rudolph Research Analytical, Hackettstown, NJ, USA). NMR spectra were determined on a Bruker $500 \mathrm{MHz}$ NMR spectrometer (Bruker BioSpin AG Industriestrasse, Fällanden, Switzerland) at $500 \mathrm{MHz}$ for ${ }^{1} \mathrm{H}-$ and $125 \mathrm{MHz}$ for ${ }^{13} \mathrm{C}-\mathrm{NMR}$ (internal standard: tetramethylsilane). Negative- and positive-ion mode HRESI-TOF-MS were obtained on an Agilent Technologies 6520 Accurate-Mass Q-TOF LC/MS spectrometer (Agilent Corp., Santa Clara, CA, USA).

Column chromatographies (CC) were performed on macroporous resin D101 (Haiguang Chemical

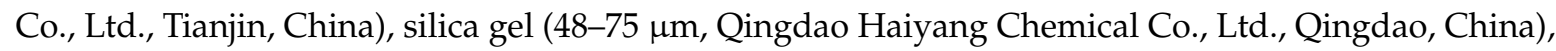
ODS (40-63 m, YMC Co., Ltd., Tokyo, Japan), and Sephadex LH-20 (Ge Healthcare Bio-Sciences, Uppsala, Sweden). Preparative high performance liquid chromatography (PHPLC) columns, Cosmosil 5C 18 -MS-II (20 mm i.d. $\times 250 \mathrm{~mm}$, Nakalai Tesque, Inc., Tokyo, Japan), were used to separate the constituents.

\subsection{Plant Material}

The seeds of L. apetalum were collected from Anguo city, China, and identified by Dr. Li Tianxiang (The Hall of Traditional Chinese Medicines (TCM) Specimens, Tianjin University of TCM, Tianjin, China). The voucher specimen was deposited at the Academy of Traditional Chinese Medicine of Tianjin University of TCM (No. 20120501).

\subsection{Extraction and Isolation}

The seeds of L. apetalum $(10 \mathrm{~kg})$ were treated with the same experimental process as reported in reference [1,2], as a result, the $95 \% \mathrm{EtOH}$ (Fraction 1) and $\mathrm{H}_{2} \mathrm{O}$ (Fraction 2) eluates were obtained.

Fraction 1 (80 g) was subjected to silica gel CC $\left(\mathrm{CHCl}_{3}-\mathrm{MeOH}(100: 0 \rightarrow 100: 5, v / v) \rightarrow\right.$ $\mathrm{CHCl}_{3}-\mathrm{MeOH}-\mathrm{H}_{2} \mathrm{O}(10: 3: 1 \rightarrow 6: 4: 1$, lower layer, $\left.v / v) \rightarrow \mathrm{MeOH}\right)$ to yield sixteen fractions (Fr. 1-1-1-16). Fractions 1-7 (12.5 g) and 1-8 (12.0 g) were isolated by ODS CC (MeOH- ${ }_{2} \mathrm{O}(20 \% \rightarrow 30 \% \rightarrow 40 \% \rightarrow$ $50 \% \rightarrow 70 \% \rightarrow 100 \%, v / v)$ ); as a result, fifteen (Fr. 1-7-1-1-7-15) and eleven fractions (Fr. 1-8-1-1-8-11) were obtained, respectively. Fraction 1-7-1 (699.0 mg) was prepared by PHPLC $\left[\mathrm{CH}_{3} \mathrm{CN}-\mathrm{H}_{2} \mathrm{O}(5: 95\right.$, $v / v)+1 \% \mathrm{HOAc}]$ to give thymidine $(22,11.1 \mathrm{mg})$. Fraction 1-8-1 (253.1 $\mathrm{mg})$ was purified by PHPLC $\left[\mathrm{CH}_{3} \mathrm{CN}-\mathrm{H}_{2} \mathrm{O}(8: 92, v / v)+1 \% \mathrm{HOAc}\right]$ to yield $3^{\prime}, 5^{\prime}$-dimethoxy-4-O- $\beta$-D-glucopyranosyl cinnamic acid (14, $29.7 \mathrm{mg})$. Fraction 1-8-3 (579.2 mg) was separated by PHPLC $\left(\mathrm{CH}_{3} \mathrm{CN}-\mathrm{H}_{2} \mathrm{O}(1: 99, v / v)+1 \% \mathrm{HOAc}\right)$, and adenosine $(23,22.7 \mathrm{mg})$ was gained. Fraction 1-8-4 $(1.3 \mathrm{~g})$ was isolated by PHPLC $\left(\mathrm{CH}_{3} \mathrm{CN}-\mathrm{H}_{2} \mathrm{O}\right.$ $(9: 91, v / v)+1 \%$ HOAc) to yield seven fractions (Fr. 1-8-4-1-1-8-4-7). Fraction 1-8-4-5 (130.9 mg) was further purified by PHPLC $\left(\mathrm{MeOH}-\mathrm{H}_{2} \mathrm{O}(22: 78, v / v)+1 \%\right.$ HOAc) to yield sinapoylglucose (15, $7.3 \mathrm{mg})$. Fraction 1-8-7 (573.6 mg) was separated by Sephadex LH-20 CC $\left(\mathrm{MeOH}-\mathrm{H}_{2} \mathrm{O}(1: 1, v / v)\right)$ and PHPLC $\left(\mathrm{CH}_{3} \mathrm{CN}-\mathrm{H}_{2} \mathrm{O}(15: 85, v / v)+1 \% \mathrm{HOAc}\right)$ to give lariciresinol 4'-O- $\beta$-D-glucopyranoside (19, $6.5 \mathrm{mg})$. Fraction 1-8-8 (1.1 g) was prepared by PHPLC $\left(\mathrm{CH}_{3} \mathrm{CN}-\mathrm{H}_{2} \mathrm{O}(16: 84, v / v)+1 \% \mathrm{HOAc}\right)$, and $(7 S, 8 R)$-aegineoside $(\mathbf{2 0}, 10.1 \mathrm{mg})$ was yielded. Fraction 1-8-10 (917.9 $\mathrm{mg})$ was purified by PHPLC $\left(\mathrm{CH}_{3} \mathrm{CN}-\mathrm{H}_{2} \mathrm{O}(13: 87, v / v)+1 \% \mathrm{HOAc}\right)$ to obtain astragalin $(4,4.6 \mathrm{mg})$ and isorhamnetin 3-O- $\beta$-D-glucopyranoside $(9,21.3 \mathrm{mg})$. Fraction 1-8-11 (1.3 g) was isolated by PHPLC $\left(\mathrm{CH}_{3} \mathrm{CN}-\mathrm{H}_{2} \mathrm{O}\right.$ $(25: 75, v / v))$ to give $1(E), 2(E)$-di-O-sinapoyl $\beta$-D-glucopyranoside $(\mathbf{1 7}, 414.4 \mathrm{mg})$. Fraction $1-12(8.0 \mathrm{~g})$ was subjected to ODS CC (MeOH- $\left.\mathrm{H}_{2} \mathrm{O}(10 \% \rightarrow 20 \% \rightarrow 30 \% \rightarrow 40 \% \rightarrow 50 \% \rightarrow 70 \% \rightarrow 100 \%, v / v)\right)$, and nine fractions (Fr. 1-12-1-1-12-9) were given. Fraction 1-12-8 (1.4 g) was further prepared by PHPLC $\left(\mathrm{CH}_{3} \mathrm{CN}-\mathrm{H}_{2} \mathrm{O}(14: 86, v / v)+1 \%\right.$ HOAc) to yield sinapoyl-9-sucrosecoside (16, $\left.370.6 \mathrm{mg}\right)$. Fraction 1-12-9 (2.1 g) was purified by PHPLC $\left(\mathrm{MeOH}-\mathrm{H}_{2} \mathrm{O}(40: 60, v / v)+1 \% \mathrm{HOAc}\right)$ to obtain 1,2-disinapoylgentiobiose $(\mathbf{1 8}, 1.3 \mathrm{~g})$ and drabanemoroside $(\mathbf{6}, 57.3 \mathrm{mg})$. Fraction 1-13 (13.7 g) was isolated by PHPLC $\left(\mathrm{MeOH}-\mathrm{H}_{2} \mathrm{O}(15: 85 \rightarrow 30: 70 \rightarrow 38: 62 \rightarrow 48: 52, v / v) \rightarrow \mathrm{MeOH}\right)$ to give twenty-one fractions (Fr. 1-13-1-1-13-21). Fraction 1-13-3 (606.1 mg) was purified by PHPLC $\left(\mathrm{CH}_{3} \mathrm{CN}-\mathrm{H}_{2} \mathrm{O}\right.$ $(5: 95, v / v)+1 \%$ HOAc) to gain apetalumoside D (2, $120.0 \mathrm{mg})$. Fraction 1-13-4 (780.2 mg) was separated by PHPLC $\left(\mathrm{CH}_{3} \mathrm{CN}-\mathrm{H}_{2} \mathrm{O}(8: 92, v / v)+1 \%\right.$ HOAc) to yield L-tryptophan (21, $\left.102.4 \mathrm{mg}\right)$. Fraction 1-13-6 (543.7 mg) was further purified by PHPLC $\left(\mathrm{CH}_{3} \mathrm{CN}-\mathrm{H}_{2} \mathrm{O}(8: 92, v / v)\right)$ to obtain 
4,9-di-O- $\beta$-D-glucosyl sinapoyl alcohol (13, $32.0 \mathrm{mg})$. Fraction 1-13-16 (217.6 mg) was isolated by PHPLC $\left(\mathrm{CH}_{3} \mathrm{CN}-\mathrm{H}_{2} \mathrm{O}(16: 84, v / v)\right)$, and isorhamnetin 3,4'-O- $\beta$-D-diglucoside (10, $\left.35.2 \mathrm{mg}\right)$ was yielded. Fraction 1-13-17 (369.6 mg) was prepared by PHPLC $\left(\mathrm{CH}_{3} \mathrm{CN}-\mathrm{H}_{2} \mathrm{O}(18: 82, v / v)\right)$ to gain apetalumoside $\mathrm{C}_{1}(\mathbf{1}, 54.1 \mathrm{mg})$. Fraction 1-13-20 $(779.2 \mathrm{mg})$ was separated by PHPLC $\left(\mathrm{CH}_{3} \mathrm{CN}-\mathrm{H}_{2} \mathrm{O}\right.$ $(16: 84, v / v))$ to obtain quercetin 3-O- $\alpha$-L-rhamnopyranosyl $(1 \rightarrow 2)-\alpha$-L-arabinopyranoside $(8,273.6 \mathrm{mg})$. Fraction 1-14 (8.0 g) was subjected to Sephadex LH-20 CC (MeOH- $\left.\mathrm{H}_{2} \mathrm{O}(1: 1, v / v)\right)$, and seven fractions (Fr. 1-14-1-1-14-7) were given. Fraction 1-14-7 $(477.8 \mathrm{mg})$ was separated by PHPLC $\left(\mathrm{CH}_{3} \mathrm{CN}-\mathrm{H}_{2} \mathrm{O}\right.$ $(14: 86, v / v)+1 \% \mathrm{HOAc})$ to yield 2-O-(3,4-dihydroxybenzoyl)-2,4,6-trihydroxyphenylacetic acid 4-O- $\beta$-D-glucopyranoside (12, $6.2 \mathrm{mg})$. Fraction 1-15 (14.1 g) was isolated by PHPLC $\left(\mathrm{CH}_{3} \mathrm{CN}-\mathrm{H}_{2} \mathrm{O}\right.$ $(9: 91, v / v))$, and eleven fractions (Fr. 1-15-1-1-15-11) were obtained. Fraction 1-15-1 (2.5 g) was further prepared by PHPLC $\left(\mathrm{CH}_{3} \mathrm{CN}-\mathrm{H}_{2} \mathrm{O}(8: 92, v / v)\right)$ to give quercetin 3-O- $\beta$-D-glucopyranosyl7-O- $\beta$-D-gentiobioside $(7,265.6 \mathrm{mg})$. Fraction 1-15-5 (2.3 g) was subjected to Sephadex LH-20 $\mathrm{CC}\left(\mathrm{MeOH}-\mathrm{H}_{2} \mathrm{O}(1: 1, v / v)\right)$ and finally separated by PHPLC $\left(\mathrm{CH}_{3} \mathrm{CN}-\mathrm{H}_{2} \mathrm{O}(10: 90, v / v)\right)$ to yield kaempferol 3-O- $\beta$-D-glucopyranosyl-7-O- $\beta$-D-gentiobioside $(5,197.1 \mathrm{mg})$. Fraction 1-15-8 (294.4 mg) was purified by PHPLC $\left(\mathrm{CH}_{3} \mathrm{CN}-\mathrm{H}_{2} \mathrm{O}(9: 91, v / v)\right)$ to gain isorhamnetin 3-O- $\beta$-Dglucopyranosyl-7-O- $\beta$-D-gentiobioside (11, $140.5 \mathrm{mg})$.

Meanwhile, fraction $2(4.0 \mathrm{~g})$ was isolated by PHPLC $\left(\mathrm{MeOH}-\mathrm{H}_{2} \mathrm{O}(2: 98, v / v)\right)$, and seven fractions (Fr. 2-1-2-7) were given. Fractions 2-4 (102.8 mg) and 2-5 (159.6 mg) were further purified by PHPLC $\left(\mathrm{MeOH}-\mathrm{H}_{2} \mathrm{O}(1: 99, v / v)\right)$ to yield stachyose $(\mathbf{2 4}, 40.9 \mathrm{mg})$ and 1-thio- $\beta$-Dglucopyranosyl $(1 \rightarrow 1)$-1-thio- $\alpha$-D-glucopyranoside $(3,73.3 \mathrm{mg})$. Fraction 2-6 (102.8 mg) was separated by PHPLC (MeOH- $\mathrm{H}_{2} \mathrm{O}(3: 97, v / v)$ to gain $\operatorname{TgSSTg}(25,58.3 \mathrm{mg})$.

Apetalumoside $C_{1}(\mathbf{1})$ : Yellow powder; $[\alpha]_{\mathrm{D}}^{25}-41.1^{\circ}(c=0.95, \mathrm{MeOH}) ; \mathrm{IR} v_{\max }(\mathrm{KBr}) \mathrm{cm}^{-1}: 3362$, 2937, 1699, 1653, 1600, 1516, 1457, 1340, 1286, 1179, 1113, 1066, 827; UV $\lambda_{\max }(\mathrm{MeOH}) \mathrm{nm}(\log \varepsilon)$ : 334 (4.19), 266 (4.09), 245 (4.20). ${ }^{1} \mathrm{H}-\left(\mathrm{DMSO}-d_{6}, 500 \mathrm{MHz}\right.$ ) and ${ }^{13} \mathrm{C}-\mathrm{NMR}$ (DMSO- $d_{6}, 125 \mathrm{MHz}$ ) spectroscopic data, see Table 1. HRESI-TOF-MS: Negative-ion mode $m / z 977.2555[\mathrm{M}-\mathrm{H}]^{-}$(calcd. $^{-}$ for $\left.\mathrm{C}_{44} \mathrm{H}_{49} \mathrm{O}_{25}, 977.2568\right)$.

Apetalumoside D (2): White powder; $[\alpha]_{\mathrm{D}}^{25}-35.3^{\circ}(c=0.94, \mathrm{MeOH}) ; \mathrm{IR} v_{\max }(\mathrm{KBr}) \mathrm{cm}^{-1}: 3399,2922$, 1616, 1519, 1463, 1336, 1222, 1113, 1025, 876, 825; UV $\lambda_{\max }(\mathrm{MeOH}) \mathrm{nm}(\log \varepsilon): 277$ (3.28, sh); 242 (3.82). ${ }^{1} \mathrm{H}-\left(\mathrm{DMSO}-d_{6}, 500 \mathrm{MHz}\right.$ ) and ${ }^{13} \mathrm{C}-\mathrm{NMR}$ (DMSO- $\left.d_{6}, 125 \mathrm{MHz}\right)$ spectroscopic data, see Table 2. HRESI-TOF-MS: Positive-ion mode $m / z 593.1333$ [M + Na] $]^{+}$(calcd. for $\mathrm{C}_{22} \mathrm{H}_{34} \mathrm{O}_{13} \mathrm{~S}_{2} \mathrm{Na}$, 593.1333).

1-Thio- $\beta$-D-glucopyranosyl $(1 \rightarrow 1)$-1-thio- $\alpha$-D-glucopyranoside (3): White powder. $[\alpha]_{\mathrm{D}}^{25}+184.5^{\circ}(c=0.97$, $\left.\mathrm{H}_{2} \mathrm{O}\right)$; IR $v_{\max }(\mathrm{KBr}) \mathrm{cm}^{-1}: 3368,2888,1636,1411,1356,1273,1097,1042,874 ;{ }^{1} \mathrm{H}^{-}\left(\mathrm{D}_{2} \mathrm{O}, 500 \mathrm{MHz}\right)$ and ${ }^{13} \mathrm{C}-\mathrm{NMR}\left(\mathrm{D}_{2} \mathrm{O}, 125 \mathrm{MHz}\right)$ spectroscopic data, see Table 3. HRESI-TOF-MS: Positive-ion mode $\mathrm{m} / \mathrm{z}$ $391.0739[\mathrm{M}+\mathrm{H}]^{+}$(calcd. for $\mathrm{C}_{12} \mathrm{H}_{23} \mathrm{O}_{10} \mathrm{~S}_{2}, 391.0727$ ).

Sinapoyl-9-sucrosecoside (16): Pale yellow powders; The NMR data of $\mathbf{1 6}$ in DMSO- $d_{6}$ is first reported. ${ }^{1} \mathrm{H}-\mathrm{NMR}$ (DMSO- $\left.d_{6}, 500 \mathrm{MHz}\right) \delta: 6.89(2 \mathrm{H}, \mathrm{s}, \mathrm{H}-2,6), 7.60(1 \mathrm{H}, \mathrm{d}, J=16.0 \mathrm{~Hz}, \mathrm{H}-7), 6.44(1 \mathrm{H}, \mathrm{d}$, $J=16.0 \mathrm{~Hz}, \mathrm{H}-8), 3.65\left((1 \mathrm{H}, \mathrm{d}, J=12.5 \mathrm{~Hz}), 3.69(1 \mathrm{H}, \mathrm{d}, J=12.5 \mathrm{~Hz}), \mathrm{H}_{2}-1^{\prime}\right), 3.87\left(1 \mathrm{H}, \mathrm{d}, J=10.0, \mathrm{H}-3^{\prime}\right)$, $4.12\left(1 \mathrm{H}, \mathrm{dd}, J=8.0,10.0 \mathrm{~Hz}, \mathrm{H}-4^{\prime}\right), 4.18\left(1 \mathrm{H}, \mathrm{m}, \mathrm{H}-5^{\prime}\right),(4.32(1 \mathrm{H}, \mathrm{dd}, J=6.0,12.0 \mathrm{~Hz}), 4.55(1 \mathrm{H}$, br. d, ca. $\left.\left.J=12 \mathrm{~Hz}, \mathrm{H}_{2}-6^{\prime}\right)\right), 5.46\left(1 \mathrm{H}, \mathrm{d}, J=3.0 \mathrm{~Hz}, \mathrm{H}-1^{\prime \prime}\right), 3.54\left(1 \mathrm{H}, \mathrm{dd}, J=3.0,9.5 \mathrm{~Hz}, \mathrm{H}-2^{\prime \prime}\right), 3.82(1 \mathrm{H}, \mathrm{dd}, J=9.5$, $\left.9.5 \mathrm{~Hz}, \mathrm{H}-3^{\prime \prime}\right), 3.41\left(1 \mathrm{H}, \mathrm{dd}, J=9.5,9.5 \mathrm{~Hz}, \mathrm{H}-4^{\prime \prime}\right), 4.18\left(1 \mathrm{H}, \mathrm{m}, \mathrm{H}-5^{\prime \prime}\right),(3.83(1 \mathrm{H}, \mathrm{m}$, overlapped), 3.92 $(1 \mathrm{H}$, br. d, ca. $\left.J=11 \mathrm{~Hz}), \mathrm{H}_{2}-6^{\prime \prime}\right), 3.87\left(6 \mathrm{H}, \mathrm{s}, 3,5-\mathrm{OCH}_{3}\right) ;{ }^{13} \mathrm{C}-\mathrm{NMR}$ (DMSO- $\left.d_{6}, 125 \mathrm{MHz}\right) \delta: 126.5(\mathrm{C}-1)$, 106.8 (C-2,6), 149.2 (C-3,5), 139.3 (C-4), 147.3 (C-7), 115.5 (C-8), 169.2 (C-9), 64.1 (C-1'), $105.1\left(\mathrm{C}-2^{\prime}\right), 83.6$ $\left(\mathrm{C}-3^{\prime}\right), 76.0\left(\mathrm{C}-4^{\prime}\right), 79.0\left(\mathrm{C}-5^{\prime}\right), 65.1\left(\mathrm{C}-6^{\prime}\right), 93.1\left(\mathrm{C}-1^{\prime \prime}\right), 73.0\left(\mathrm{C}-2^{\prime \prime}\right), 74.5\left(\mathrm{C}-3^{\prime \prime}\right), 71.7\left(\mathrm{C}-4^{\prime \prime}\right), 71.9\left(\mathrm{C}-5^{\prime \prime}\right)$, $64.1\left({\left.\mathrm{C}-6^{\prime \prime}\right)}^{\prime}, 56.9\left(3,5-\mathrm{OCH}_{3}\right)\right.$; HRESI-TOF-MS: Negative-ion mode $m / z 547.1680\left[\mathrm{M}-\mathrm{H}^{-}{ }^{-}\right.$(calcd. for $\left.\mathrm{C}_{23} \mathrm{H}_{31} \mathrm{O}_{15}, 547.1668\right)$.

Acid Hydrolysis of 1: the solution of compound $1(2.0 \mathrm{mg})$ in $1 \mathrm{M} \mathrm{HCl}(1 \mathrm{~mL})$ was treated by using the same method as described in reference [1,2]: 1 was heated under reflux for $3 \mathrm{~h}$. The reaction mixture was then analyzed by $\mathrm{CH}_{3} \mathrm{CN}-\mathrm{H}_{2} \mathrm{O}(70: 30, v / v$; flow rate $1.0 \mathrm{~mL} / \mathrm{min})$. As a result, D-glucose 
was detected from the aqueous phase of $\mathbf{1}$ by comparison of its retention time and optical rotation with that of the authentic sample, D-glucose $\left(t_{\mathrm{R}} 8.8 \mathrm{~min}\right.$ (positive)).

\subsection{Evaluation of Effects on Sodium Oleate-Induced TG Overloading in HepG2 Cells}

Materials: HepG2 cells were purchased from Cell Resource Center of Institute of Basic Medical Sciences, Chinese Academy of Medical Sciences \& Peking Union Medical College (Beijing, China). Dulbecco's modified Eagle's medium (DMEM), penicillin and streptomycin were purchased from Thermo Scientific (Waltham, MA, USA). Fetal Bovine Serum (FBS) was obtained from Mediatech (Herndon, VA, USA). TG assay kits were purchased from Biosino Bio-Technology And Science Inc. (Beijing, China). Sodium oleate (SO) and orlistat were obtained from Sigma-Aldrich Corporation (St. Louis, MO, USA).

Cell culture: HepG2 cells were routinely cultured in DMEM-based medium as described before [25]. After cells reached about $80 \%$ confluence and were seeded at a density of 80,000 cells $/ \mathrm{mL}$ in 48-multiwell plates for $24 \mathrm{~h}$, the experiments were then performed.

Induction and evaluation of TG overloading: TG overloading was induced as described before [25]. Briefly, HepG2 cells at 80\% confluence were exposed to $200 \mu \mathrm{mol} / \mathrm{L} \mathrm{SO}$ for $48 \mathrm{~h}$. Meanwhile, the tested isolates at the indicated concentrations were added in the presence of SO. Orlistat $(5 \mu \mathrm{mol} / \mathrm{L}) \mathrm{was}$ selected as the positive control and the medium without SO was used as the negative control. At the end of the experiment, the intracellular TG content was determined using a commercial TG assay kit after cells were rinsed by phosphate-buffered saline and lysed. The absorbance was analyzed at $492 \mathrm{~nm}$. Under the selected concentrations in this study, according to pre-tests, no obvious influence was observed on cell viability (data not shown). The measurement was made in triplicate.

\subsection{Statistical Analysis}

Statistical analyses were undertaken with SPSS v12.0 (SPSS, Chicago, IL, USA). The significance of the differences between the mean values was determined using an analysis of variance (ANOVA). The differences were considered statistically significant at $p<0.05$.

\section{Conclusions}

Summed up, twenty-five compounds (1-25) including three new ones, apetalumosides $C_{1}(\mathbf{1})$, $\mathrm{D}(2)$, and 1-thio- $\beta$-D-glucopyranosyl $(1 \rightarrow 1)$-1-thio- $\alpha$-D-glucopyranoside (3), were obtained from the seeds of L. apetalum. Among the known isolates, 5-8, 10-13, 16-20, and 25 were obtained from the genus for the first time; 4, 14, 15, 21-24 were isolated from the species for the first time. Meanwhile, the NMR data of 16 was first reported here. Their structures were determined by means of chemical and spectroscopic methods. Moreover, their inhibitory effects on TG overloading were evaluated in HepG2 cells. The results showed that phenol compounds, including five flavonoids (7-11), five sinapic acid groups $(\mathbf{1 3}, \mathbf{1 4}, \mathbf{1 6}-\mathbf{1 8})$ and one lignin (20), together with two new compounds (1 and 2$)$ as well as two other isolates (21 and 25) have significant TG-lowering effects, among of which, 10, 13 and 21 exhibited a level of activities almost comparable to that of orlistat. It is suggested that the above compounds contained in the L. apetalum might be part of the material basis involved in the lipid metabolism.

Acknowledgments: This work was financially supported by programs for National Natural Science Foundation of China (81673688), Changjiang Scholars and Innovative Research Team in University (PCSIRT, No. IRT_14R41).

Author Contributions: Yi Zhang and Tao Wang designed the research and wrote the manuscript; Sijian Wang, Pingping Shi, and Lu Qu performed the experimental work; Jingya Ruan and Shengcai Yang retrieved literature; Haiyang Yu perfected language. All authors discussed, edited and approved the final version.

Conflicts of Interest: The authors declare no conflict of interest. 


\section{References}

1. Han, L.; Shi, P.; Dong, Y.; Wang, T.; Li, X.; Hao, J.; Zhang, Y.; Wang, T. New rare sinapoyl acylated flavonoid glycosides obtained from the seeds of Lepidium apetalum Willd. Molecules 2015, 20, 13982-13996. [PubMed]

2. Shi, P.; Chao, L.; Wang, T.; Liu, E.; Han, L.; Zong, Q.; Li, X.; Zhang, Y.; Wang, T. New bioactive flavonoid glycosides isolated from the seeds of Lepidium apetalum Willd. Fitoterapia 2015, 103, 197-205. [PubMed]

3. Wei, Y.; Xie, Q.; Fisher, D.; Sutherland, I.A. Separation of patuletin-3-O-glucoside, astragalin, quercetin, kaempferol and isorhamnetin from Flaveria bidentis (L.) Kuntze by elution-pump-out high-performance counter-current chromatography. J. Chromatogr. A 2011, 1218, 6206-6211. [PubMed]

4. Bacon, J.D.; Mabry, T.J. Flavonol glycosides of Nerisyrenia (Cruciferae). Phytochemistry 1976, 15, 1087-1088. [CrossRef]

5. Moon, S.S.; Rahman, M.A.; Manir, M.M.; Jamal Ahamed, V.S. Kaempferol glycosides and cardenolide glycosides, cytotoxic constituents from the seeds of Draba nemorosa (Brassicaceae). Arch. Pharm. Res. 2010, 33, 1169-1173. [CrossRef] [PubMed]

6. Halabalaki, M.; Urbain, A.; Paschali, A.; Mitakou, S.; Tillequin, F.; Skaltsounis, A.L. Quercetin and kaempferol 3-O-[ $\alpha$-L-rhamnopyranosyl-( $1 \rightarrow 2)-\alpha$-L-arabinopyranoside]-7-O- $\alpha$-L-rhamnopyranosides from Anthyllis hermanniae: Structure determination and conformational studies. J. Nat. Prod. 2011, 74, 1939-1945. [CrossRef] [PubMed]

7. Atay, I.; Kirmizibekmez, H.; Goren, A.C.; Yesilada, E. Secondary metabolites from Sambucus ebulus. Turk. J. Chem. 2015, 39, 34-41. [CrossRef]

8. Park, S.H.; Kim, H.; Rhyu, D.Y. Flavonoids from the stems of eastern picklypear Opuntia humifusa, Cactaceae. J. Appl. Biol. Chem. 2007, 50, 254-258.

9. Zhang, Y.B.; Wu, P.; Zhang, X.L.; Xia, C.; Li, G.Q.; Ye, W.C.; Wang, G.C.; Li, Y.L. Phenolic compounds from the flowers of Bombax malabaricum and their antioxidant and antiviral activities. Molecules 2015, 20, 19947-19957. [CrossRef] [PubMed]

10. Nakayama, R.; Kikuzaki, H.; Nakatani, N.; Hisashi, H. Antioxidative activity of constituents from fennel seeds. J. Home Econ. Jpn. 1996, 47, 1193-1200.

11. Hashimoto, K.; Katsuhara, T.; Niitsu, K.; Ikeya, Y.; Okada, M.; Mitsuhashi, H. Two glycosides from roots of Asiasarum sieboldi. Phytochemistry 1992, 31, 2477-2480. [CrossRef]

12. Pauli, G.F.; Junior, P. Phenolic glycosides from Adonis aleppica. Phytochemistry 1995, 38, 1245-1250. [CrossRef]

13. Strack, D.; Dahlbender, B.; Grotjahn, L.; Wray, V. 1,2-disinapolylglucose accumulated in cotyledons of dark-grown raphanus sativus seedlings. Phytochemistry 1984, 23, 657-659. [CrossRef]

14. Price, K.R.; Casuscelli, F.; Colquhoun, I.J.; Rhodes, M.J.C. Hydroxycinnamic acid esters from Broccoli florets. Phytochemistry 1997, 45, 1683-1687. [CrossRef]

15. Li, T.; Zhang, W.; Gu, Z.; Liu, W.; Zhang, C.; Liu, R. Lignans from Patrinia scabra. Zhongcaoyao 2005, 36, 338-340.

16. Yang, B.H.; Zhang, W.D.; Liu, R.H.; Li, T.Z.; Zhang, C.; Zhou, Y.; Su, J. Lignans from bark of Larix olgensis var. koreana. J. Nat. Prod. 2005, 68, 1175-1179. [CrossRef] [PubMed]

17. Kizu, H.; Shimana, H.; Tomimori, T. Studies on the constituents of Clematis species. VI. The constituents of Clematis stans Sieb. et Zucc. Chem. Pharm. Bull. 1995, 43, 2187-2194. [CrossRef] [PubMed]

18. Yuan, X.; Gao, H.; Chen, L.; Zhang, Q.; Wang, Z. A new lignan from stems of Sargentodoxa cuneata. Zhongguo Zhongyao Zazhi 2013, 38, 2118-2124. [PubMed]

19. Jia, L.; Zhong, L.; Li, H.; Jing, L. Chemical constituents in water fraction of Abelmoschus esculentus. Zhongcaoyao 2011, 42, 2186-2188.

20. Youssef, D.T.A.; Badr, J.M.; Shaala, L.A.; Mohamed, G.A.; Bamanie, F.H. Ehrenasterol and biemnic acid; new bioactive compounds from the Red Sea sponge Biemna ehrenbergi. Phytochem. Lett. 2015, 12, $296-301$. [CrossRef]

21. Abou-Hussein, D.R.; Badr, J.M.; Youssef, D.T.A. Nucleoside constituents of the Egyptian tunicate Eudistoma laysani. Nat. Prod. Sci. 2007, 13, 229-233.

22. Montilla, A.; Corzo, N.; Olano, A.; Jimeno, M.L. Identification of oligosaccharides formed during stachyose hydrolysis by Pectinex Ultra SP-L. J. Agric. Food Chem. 2009, 57, 5007-5013. [CrossRef] [PubMed]

23. Shaw, C.F., III; Eldridge, J.; Cancro, M.P. ${ }^{13}$ C-NMR studies of aurothioglucose: Ligand exchange and redox disproportionation reactions. J. Inorg. Biochem. 1981, 14, 267-274. [CrossRef] 
24. Ngane, A.N.; Lavault, M.; Séraphin, D.; Landreau, A.; Richomme, P. Three 1-thio- $\beta$-D-glucopyranosides from the seeds of Afrostyrax lepidophyllus Mildbr. Carbohydr. Res. 2006, 341, 2799-2802. [CrossRef] [PubMed]

25. Li, J.; Adelakun, T.A.; Wang, S.; Ruan, J.; Yang, S.; Li, X.; Zhang, Y.; Wang, T. Inhibitory effects of constituents from the aerial parts of Rosmarinus officinalis L. on triglyceride accumulation. Molecules 2017, 22, 110. [CrossRef] [PubMed]

Sample Availability: Samples of all compounds are available from the authors.

(C) 2017 by the authors. Licensee MDPI, Basel, Switzerland. This article is an open access article distributed under the terms and conditions of the Creative Commons Attribution (CC BY) license (http:/ / creativecommons.org/licenses/by/4.0/). 